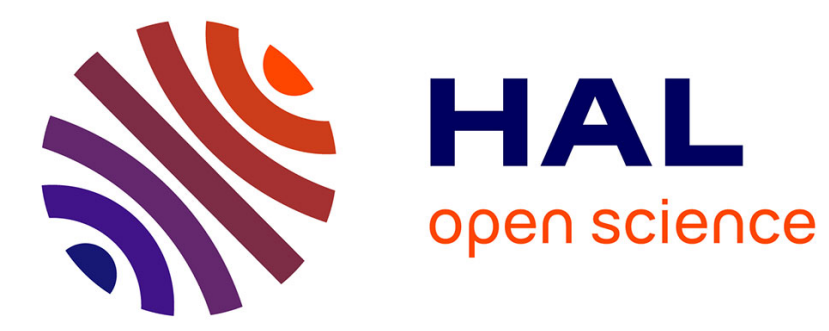

\title{
Thirteen pear species and cultivars evaluated for resistance to Cacopsylla pyri (Homoptera Psyllidae)
}

S. Berrada, T.X. Nguyen, J. Lemoine, J. Vanpoucke, D. Fournier

\section{To cite this version:}

S. Berrada, T.X. Nguyen, J. Lemoine, J. Vanpoucke, D. Fournier. Thirteen pear species and cultivars evaluated for resistance to Cacopsylla pyri (Homoptera Psyllidae). Environmental Entomology, 1995, 24 (6), pp.1604-1607. hal-02712432

\section{HAL Id: hal-02712432 \\ https://hal.inrae.fr/hal-02712432}

Submitted on 1 Jun 2020

HAL is a multi-disciplinary open access archive for the deposit and dissemination of scientific research documents, whether they are published or not. The documents may come from teaching and research institutions in France or abroad, or from public or private research centers.
L'archive ouverte pluridisciplinaire HAL, est destinée au dépôt et à la diffusion de documents scientifiques de niveau recherche, publiés ou non, émanant des établissements d'enseignement et de recherche français ou étrangers, des laboratoires publics ou privés. 


\title{
Thirteen Pear Species and Cultivars Evaluated for Resistance to Cacopsylla pyri (Homoptera: Psyllidae)
}

\author{
S. BERRADA, T. X. NGUYEN, J. LEMOINE, ${ }^{1}$ J. VANPOUCKE, ${ }^{2}$ and D. FOURNIER
}

Laboratoire d'Entomologie, Université Paul Sabatier, 118 route de Narbonne, 31062 Toulouse Cedex, France

\begin{abstract}
Environ. Entomol. 24(6): 1604-1607 (1995)
ABSTRACT Thirteen pear, Pyrus spp., cultivars were evaluated under field and laboratory conditions for resistance to Cacopsylla pyri (L.). In field studies, population growth was quantified over a 1-mo period of development. In the laboratory, the mode of host resistance was investigated by estimating oviposition and antibiosis. One cultivar and 3 pear species were found to be resistant to pear psylla ('Hosui', P. betulaefolia, P. pyrifolia, and P. ussuriensis); the remaining ones may be classified as susceptible (Doyennée du Comice, 'Williams', 'Général Leclerc', and 'Moonglow'). Antibiosis was a main factor determining resistance in the test pears, and preference for oviposition was involved to a much lesser degree.
\end{abstract}

KEY WORDS Cacopsylla pyri, pear, resistance, oviposition, antibiosis

TWO SPECIES ATTACKING pear, Cacopsylla pyri (L.) in Europe and C. pyricola (Foerster) in North America, are the most serious insect pests of commercial pear orchards. Because current control of these pests relies almost exclusively on pesticides, pear psylla populations have developed resistance to several classes of pesticides in the major pearproducing areas of Europe and North America (Harries and Burts 1965, Riedl et al. 1981, Stäubli and Antonin 1984, Van De Baan 1988, Berrada et al. 1994). Furthermore, because biological control is not sufficient to prevent damage, especially that caused by lst-generation pear psylla larvae feeding on spur leaves, the most viable solution for the management of this pest would be the use of resistant pear genotypes.

Williams et al. (1963) reported moderate injury by pear psylla to Asian pear species compared with Pyrus communis (L.). Furthermore, Westigard et al. (1970) reported C. pyricola resistance in several pear species under field and laboratory conditions and noted the tolerance in Asian pears, mainly $P$. ussuriensis (Maxim). Subsequent works demonstrated that preferences for oviposition and antibiosis were responsible for resistance in certain pear genotypes (Harris 1973). In addition to these 2 factors, nutritional qualities were found to be responsible for larval mortality when feeding on resistant pear genotypes (Butt et al. 1988, 1989).

Thirteen pear species and cultivars were evaluated under field conditions and to determine their resistance or susceptiblity to C. pyri. In addition, preferences for oviposition and antibiosis were in-

\footnotetext{
${ }^{1}$ Institut National de la Recherche Agronomique, Angers, France.

${ }^{2}$ Mathématiques Informatique Gestion, Université Paul Sabatier, 118 route de Narbonne, 31062 Toulouse Cedex, France.
}

vestigated in the laboratory to characterize the mechanism of host resistance.

\section{Materials and Methods}

Pear species and cultivars selected for experiments were P. pyrifolia (Burm), P. ussuriensis, P. betulaefolia (Bge), 'Williams', 'Doyennée du Comice', 'Général Leclerc', 'Pierre Corneille', 'Sirrine', 'Moonglow', 'Hosui', 'Xe Hua Li', 'Old Home 11', and 'Old Home 33'. Note that except P. ussuriensis, P. pyrifolia, Old Home 11, Old Home 33, and Sirrine, all the plants studied are commercially grown. Furthermore, among the 13 test pears, the most commonly cultivated varieties are Williams, Doyennée du Comice, Général Leclerc, and Pierre Corneille.

Insects were reared in our laboratory (Dargagnon and Nguyen 1984), where they have been maintained on P. communis since 1986.

Field Experiments. Three 6-yr-old pear trees (Williams) were used as rootstocks. They were over-grafted as follows: tree 1: Doyennée du Comice, Général Leclerc, Pierre Corneille, Moonglow, and Sirrine; tree 2: Old Home 11, Old Home 33, Xe Hua Li, and Hosui; tree 3: P. pyrifolia, P. ussuriensis, and $P$. betulaefolia. For each cultivar, 3 grafts per tree were realized. In all bioassays, 3 Williams shoots per tree were kept and used as reference to assess the vigor of rootstocks (that is, Williams).

Rootstock trees were over-grafted and covered with an insect-proof cage. When young pear shoots developed to an average height of $20-25 \mathrm{~cm}, 25$ pairs of mature adults were deposited on each stem of tree. Larvae from each graft were counted 3 and 7 wk after adult insects were released. 

Resistance of the test pears was rated by calculating the percentage of population size variation over a 1-mo period of development. It was calculated as:

percentage of population size variation

$$
=\frac{\mathrm{n}_{2}}{\mathrm{n}_{1}} \times 100,
$$

where $n_{1}$ and $n_{2}$ are mean numbers of larvae from each cultivar 3 and $7 \mathrm{wk}$ after tree infestation, respectively.

Laboratory Experiments. Test pears were either grafted with a dormant bud and kept under natural conditions during the winter, or bench grafted in the spring. Plants were then maintained in a greenhouse until they measured $40-45 \mathrm{~cm}$ in height. The foliage surface studied was $\approx 300 \mathrm{~cm}^{2}$. This surface area varied according to the variety but usually resulted in 10-16 leaves per plant. Each plant was infested with 15 pairs of sexually mature adults and covered with a cheesecloth sleeve cage $(50 \mathrm{~cm}$ high, $22 \mathrm{~cm}$ diameter). Forty eight hours after infestation, adults were removed from the plants, and the eggs laid on each plant were counted with the aid of a magnifying glass $(10 \times)$. Survival of eggs and larvae were recorded each day until they developed into adults. Four plants per pear were tested at $20 \pm 2^{\circ} \mathrm{C}$ and a photoperiod of 16:8 (L:D) h. The antibiosis mechanism was assessed according to Westigard et al. (1970) and Harris (1973):

$$
\begin{aligned}
& \text { percentage of survival } \\
& =\frac{\text { number of emerged adults }}{\text { number of eggs }} \times 100
\end{aligned}
$$

Statistical Analysis. Data were subjected to analysis of variance, and the Fisher protected least significant difference test (LSD) was used for means separation at $P<0.05$ (Abacus Concepts 1991).

\section{Results and Discussion}

Field Experiments. Results of the resistance screening in the field are shown in Fig. 1. Variations in pear psylla population buildup on the test pears can be distinguished after a 1-mo period of development $(P<0.05)$. Variations in population size ranged from 60 to $700 \%$. No population buildup was observed on Hosui, P. betulaefolia, P. pyrifolia, and P. ussuriensis. Larvae on these varieties decreased (Hosui) or remained stable over the test period. On the remaining cultivars, the population buildup ranged from 500 to $700 \%$. However, among these cultivars 2 groups demonstrated significant differences in pear psylla development $(P$ $<0.05$ ). Old Home 33 and Xe Hua Li had an $\approx 500 \%$ larval increase, and Général Leclerc, Sirrine, and Moonglow exhibited the highest population growth $(700 \%)$.

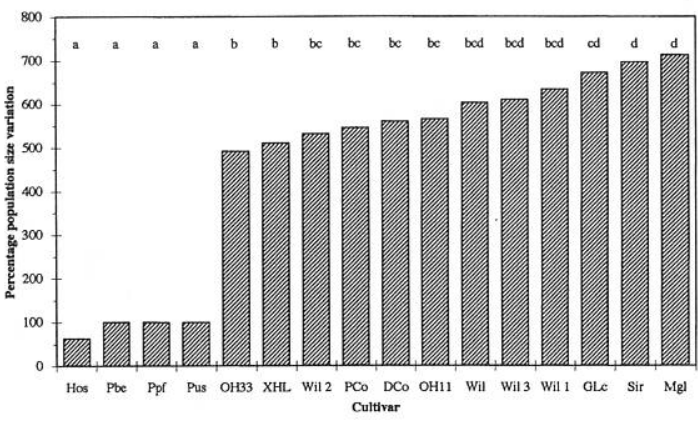

Fig. 1. Mean percentage of C. pyri population growth over a 1-mo period of development on 13 pear species and cultivars. Data are means of 3 replicates. Means followed by the same letter are not significantly different $(P$ $>0.05$, LSD). Hos, Hosui; Pbe, P. betulaefolia; Ppf, P. pyrifolia; Pus, P. ussuriensis; OH33, Old Home 33; XHL, Xe Hua Li; PCo, Pierre Corneille; DCo, Doyennée du Comice; OH11, Old Home 11; Wil, Williams; GLc, Général Leclerc; Sir, Sirrine; Mgl, Moonglow.

Figure 1 shows that the buildup of various pear psylla on the reference shoots (Williams 1, Williams 2, and Williams 3) did not differ significantly $(P>0.05)$. This indicates that the different pear grafts had not been influenced distinctly by the rootstocks.

Laboratory Experiments. Results of the oviposition preference of pear psylla to the test pears and those of antibiosis are shown in Fig. 2. Pear psylla ovipositional response showed that, overall, pears were attractive but differed distinctly on pear cultivars. Four levels of egg-laying during a 2-d oviposition could be distinguished $(P<0.05)$ (Fig. $2 A)$. In the whole, $P$. pyrifolia and $P$. betulaefolia had the smallest egg masses (130 eggs), and old Home 33 was the most preferred cultivar for oviposition (480 eggs).

In antibiosis trials, large variations among pear psylla development were observed. On 8 pears, $35 \%$ of eggs developed into adults (Fig. 2B). On $P$. betulaefolia, the percentage of survival was 0 . There were no significant differences $(P>0.05)$ in antibiosis between Général Leclerc, Moonglow, Williams, Doyennée du Comice, and Sirrine. The highest percentage of survival occurred on Sirrine; $70 \%$ of eggs completed development on this cultivar.

Figure 2 shows that pears that demonstrated higher antibiosis resistance (lower percentage of survival) were not necessarily those that presented nonpreference for oviposition. These results indicate these 2 factors did not operate similarly in resistance of the test pears. Furthermore, Figs. 1 and 2 show that pears on which pear psylla population did not develop (that is, Hosui, $P$. betulaefolia, P. pyrifolia, and P. ussuriensis) were those presenting the highest antibiosis against the pest.

Correlations between pear psylla population buildup in field experiments and oviposition and antibiosis valued in laboratory studies were calcu- 

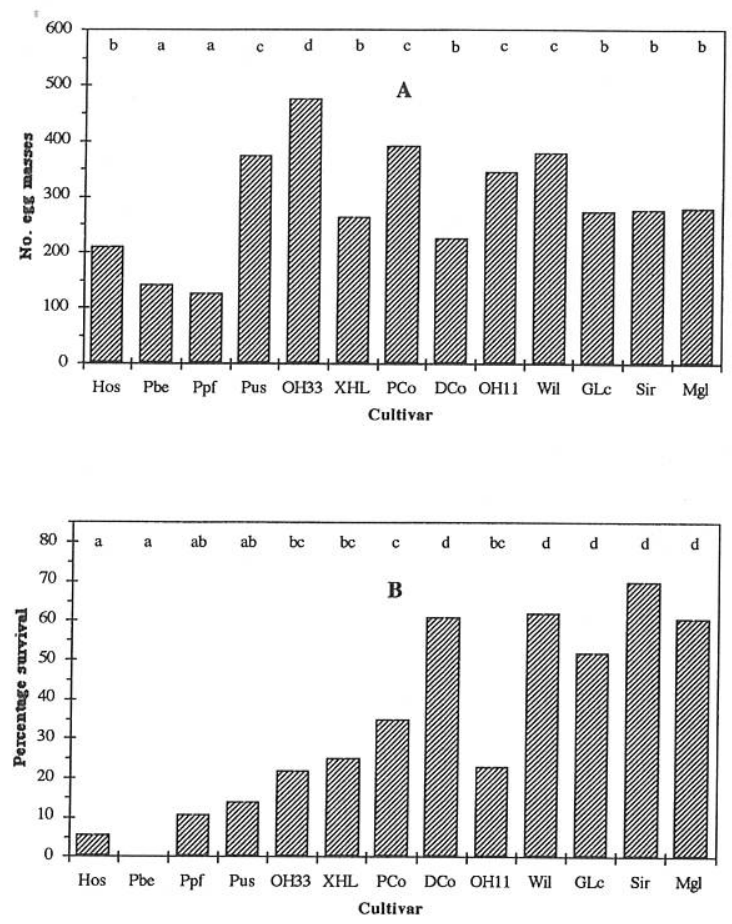

Fig. 2. Egg-masses laid by C. pyri during $2 \mathrm{~d}$ of oviposition on 13 pear species and cultivars $(\AA)$, and percentage of eggs developed into adults (B). Data are means of 4 replicates. Means followed by the same letter are not significantly different $(P>0.05$, LSD). Hos, Hosui; Pbe, P. betulaefolia; Ppf, P. pyrifolia; Pus, P. ussuriensis; OH33, Old Home 33; XHL, Xe Hua Li; PCo, Pierre Corneille; DCo, Doyennée du Comice; OH11, Old Home 11; Wil, Williams; GLc, Général Leclerc; Sir, Sirrine; Mgl, Moonglow. Note that the test pears are arranged according to results obtained in field bioassays.

lated. A significant correlation was found between antibiosis and the pest population growth $(r=$ $0.86, \mathrm{df}=12, P=0.05$ ), but preference for oviposition did not correlate with the pest population growth $(r=0.43, \mathrm{df}=12, P=0.05)$. Hence, it is assumed that antibiosis is a major mechanism determining resistance in the test pears to C. pyri, and preference for oviposition is involved to a much lesser degree.

Based on laboratory and field bioassays, Hosui, P. betulaefolia, P. pyrifolia, and P. ussuriensis may be classified as resistant to pear psylla infestation. These pears exhibited the highest antibiosis and lower preference to oviposition among the test pears (except $P$. ussuriensis, on which large numbers of eggs were laid). Our findings show that certain Asian pear species (those classified as resistant) are those among the test pears that offered more tolerance to the pest infestation. These results are consistent with those obtained by Williams et al. (1963) and Westigard et al. (1970), who found with other varieties that pear species of European origin were more favorable to pear psylla than those from Asia.
The investigation here demonstrated that antibiosis was a mode of resistance of pears to C. pyri.

Earlier studies indicated that resistance in certain pear cultivars to C. pyricola was associated with larval rejection of the resistant genotypes for feeding, and this rejection was caused by feeding inhibitors or the absence of sufficient or necessary feeding stimulants (Butt et al. 1988, 1989). The chemical composition of plants had already been demonstrated to determine their susceptibility to insect pests (Dabrowski and Bielak 1978, Hardman and Ellis 1978).

This investigation demonstrated different reactions of some pear species and cultivars to C. pyri. Pears found to be susceptible are those that are the most cultivated and the most vigorous (Doyennée du Comice, Général Leclerc, and Williams). These results quantify the observations made in French pear orchards (Geoffrion 1984). Because tree vigor is essential for the feasibility of a culture, studies focusing on the genes that are tied to vigor and those responsible for the limitation of pest development will be needed. The most tolerant pears (that is, certain Asian ones) may provide breeders a source of pest-resistance genes to incorporate into the most vigorous pears (Williams, Doyennée du Comice, and Général Leclerc).

\section{Acknowledgment}

These investigations were partially funded by Institut National de la Recherche Agronomique (AIP 90/4722).

\section{References Cited}

Abacus Concepts. 1991. StatView student. (Abacus Concepts, Berkeley, CA.

Berrada, S., D. Fournier, A. Cuany, and T. X. Nguyen. 1994. Identification of resistance mechanisms in a selected laboratory strain of Cacopsylla pyri (Homoptera: Psyllidae): altered acetylcholinesterase and detoxifying oxidases. Pestic. Biochem. Physiol. 48: 4147.

Butt, B. A., L. C. Stuart, and R. L. Bell. 1988. Feeding behavior of pear psylla (Homoptera: Psyllidae) nymphs on susceptible and resistant Pyrus germplasm. J. Econ. Entomol. 81: 1394-1397.

1989. Feeding, longevity and development of pear psylla (Homoptera: Psyllidae) nymphs on resistant and susceptible pear genotypes. J. Econ. Entomol. 82: 458-461.

Dabrowski, Z. T., and B. Bielak. 1978. Effect of some plant chemical compounds on the behavior and reproduction of spider mites (Acarina: Tetranychidae). Entomol. Exp. Appl. 24: 117-126.

Dargagnon, D., and T. X. Nguyen. 1984. Essai d'élevage de Psylla pyri en continu au laboratoire. Bulletin de l'Organisation Internationale de Lutte Biologique/ Section Régionale Ouest Paléarctique 7: 222-240.

Geoffrion, R. 1984. Les psylles du poirier: historique et situation économique. Bulletin de l'Organisation Internationale de Lutte Biologique/Section Régionale Ouest Paléarctique 7: 13-15.

Hardman, J. A., and P. R. Ellis. 1978. Host plant factors influencing the susceptibilty of cruciferous 
crops to cabbage root fly attack. Entomol. Exp. Appl. 24: 193-197.

Harries, F. H., and E. C. Burts. 1965. Insecticide resistance in pear psylla. J. Econ. Entomol. 58: 712713

Harris, M. K. 1973. Host resistance to the pear psylla in a Pyrus communis $\times$ P. ussuriensis hybrid. Environ. Entomol. 2: 883-887.

Riedl, H., P. H. Westigard, R. S. Bethell, and J. E. De Tar. 1981. Problems with chemical control of pear psylla. Calif. Agric. 35: 7-9.

Stäubli, A., and P. H. Antonin. 1984. Aménagement d'une lutte raisonnée contre les psylles du poirier, Psylla pyri, en Suisse, particulièrement en Valais et dans le bassin Lémanique. Bulletin de l'Organisation
Internationale de Lutte Biologique/Section Régionale Ouest Paléarctique 7: 258-264.

Van De Baan, H. 1988. Factors influencing pesticide resistance in Psylla pyricola Foerster and susceptibility in its mirid predator, Deraecoris brevis Knight. Ph.D. dissertation, Oregon State University, Corvallis.

Westigard, P. H., M. N. Westwood, and P. B. Lombard. 1970. Host preference and resistance of $P y$ rus species to the pear psylla, P. pyricola (Foerster). J. Am. Soc. Hortic. Sci. 95: 34-36.

Williams, M. W., L. P. Batjer, E. S. Degman, and E. C. Burts. 1963. Susceptibility of some pear species to injury from pear psylla. Proc. Am. Soc. Hortic. Sci. 82: 109-113.

Received for publication 13 June 1995; accepted 16 August 1995. 
